\title{
Export and Economic Growth in Saudi Arabia: The Granger Causality Test
}

\author{
Saif Sallam Alhakimi ${ }^{1}$ \\ 'Associate Professor of International Economics, University of Bisha, Saudi Arabia, and University of Hodeida, \\ Temen \\ Email:saifalhakimi@yahoo.com
}

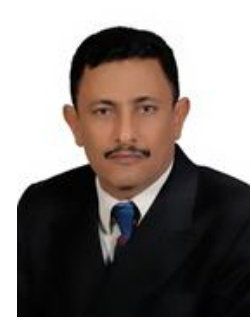

\begin{abstract}
An export-led growth strategy aims to encourage producers to export their goods through various economic and governmental policies. This study was carried out with the primary objective of investigating the relationship between exports and economic growth in the Kingdom of Saudi Arabia (hereafter referred to as the KSA), specifically by examining the causality between exports and KSA's economic growth. There are four main propositions for the relationship between exports and economic growth: export-led growth (ELG), growth-driven exports (GDE), and feedback relationships between exports and economic growth. To complete this study, samples were used based on 37 years of annual data. The study also employed a unit root test, a co-integration test, and the Granger causality test to observe the causal relationship between exports and economic growth. Data were collected for exports, which were expressed according to export growth. Economic growth, meanwhile, was measured according to gross domestic product (GDP) per capita and expressed in terms of US dollars. The result of this study found that GDP per capita significantly influenced exports, while exports did not affect GDP.
\end{abstract}

Keywords: Growth, Export, Co-integration, Error-correction, Causality.

JEL Classification: 04.

Citation | SaifSallam Alhakimi (2018). Export and Economic Growth in Saudi Arabia: The Granger Causality Test. Asian Journal of Economics and Empirical Research, 5(1): 29-35. History:

Received: 5 March 2018

Revised: 27 March 2018

Accepted: 2 April 2018

Published: 4 April 2018

Licensed: This work is licensed under a Creative Commons

Attribution 3.0 License $(\mathrm{cc}) \mathbf{B}$.

Publisher:Asian Online Journal Publishing Group
Funding: This study received no specific financial support.

Competing Interests: The author declares that there are no conflicts of interests regarding the publication of this paper.

Transparency: The author confirms that the manuscript is an honest, accurate, and transparent account of the study was reported; that no vital features of the study have been omitted; and that any discrepancies from the study as planned have been explained.

Ethical: This study follows all ethical practices during writing.

\section{Contents}

1. Introduction

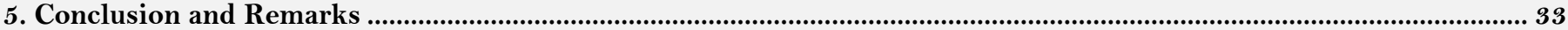

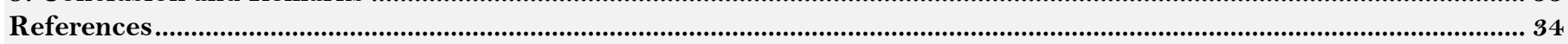

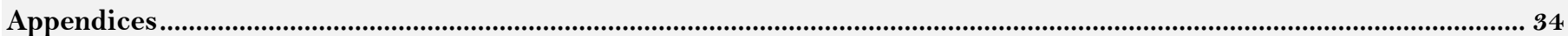




\section{Introduction}

Export is a function of international trade where goods produced in one country are shipped to another country for sale or trade. Sales from exports contribute to a nation's gross domestic product and play an important role in a developed economy. A popular debate among economists has focused on the relationship between export growth and economic growth, because a successful macro-economic strategy leads to a better quality of life for people. As a consequence, rapid GPD growth has become an important objective for many countries, including the KSA.

An important question immediately confuses this objective, however: Does the promotion of exports lead to greater economic growth or vice versa? The export of goods and services is an important source of foreign income, and this can relieve the pressure on budgetary expenses and create new employment opportunities. An export-led growth strategy therefore aims to encourage producers to find export markets for their goods through various economic and governmental policies. This study addresses the above question by examining the causality between exports and the KSA's economic growth.

The reminder of this paper proceeds as follows: Section 2 covers the literature review. Section 3 introduces an experimental study. Section 4 reports the empirical results. Section 5 conclusion and remarks.

\subsection{Overview of Exports in the KSA}

Based on the UN Cometrade Database (2016) the KSA's main exports are mineral fuels, oils, and distillation products (76\% of total exports); plastics and articles derived thereof (7.5\%); organic chemicals (5.1\%); ships, boats, and other floating structures (1.2\%); aluminum and articles derived thereof (1\%); and machinery, nuclear reactors, and boilers $(0.85 \%)$. The KSA also exports oil, inorganic chemicals, precious metals, isotopes, non-railway vehicles, and other products. Its main export markets are the United Arab Emirates (14\% of total exports), China (12\%), India (6.3\%), Singapore (4.9\%), Egypt (4.1\%), Turkey (3.6\%), Qatar (3.3\%), Kuwait (3.3\%), Belgium (3.2\%), Bahrain $(3.1 \%)$, the United States (3.1\%), Jordan (3.1\%), and Malaysia (2.8\%). Other exports include South Korea, Pakistan, Oman, Italy, Vietnam, Japan, Spain, Thailand, Algeria, the United Kingdom, and Yemen.

\subsection{The Trend for the KSA's Export Flows}

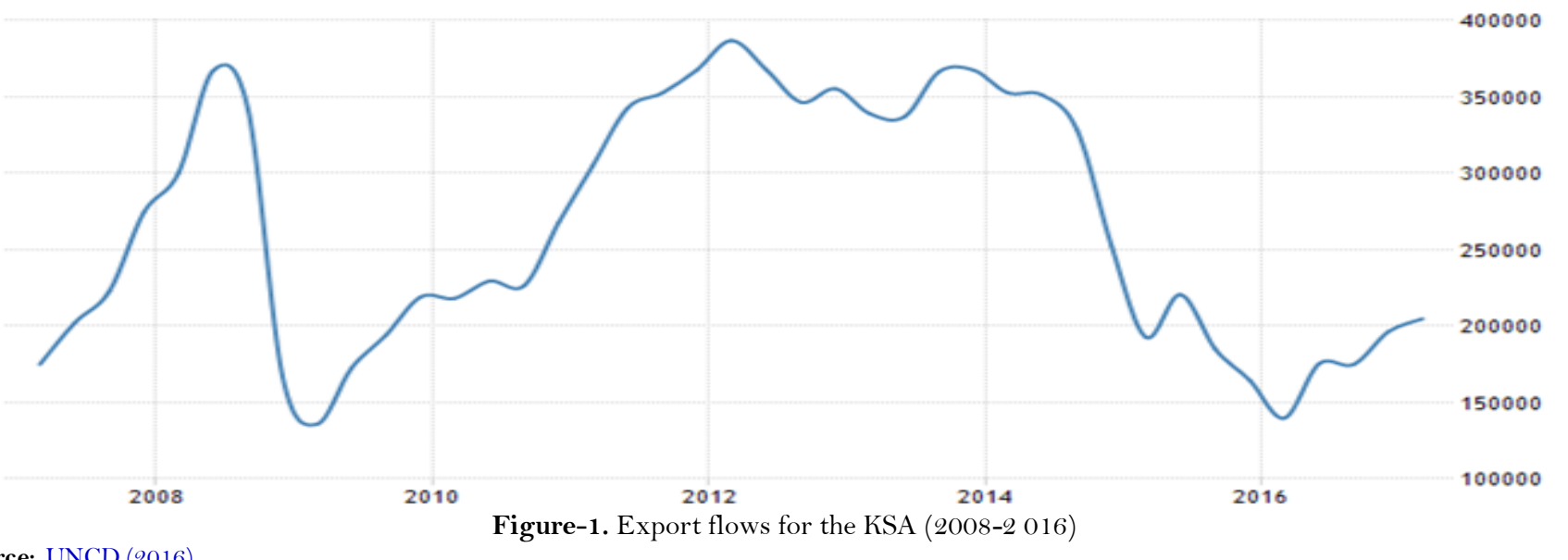

Source: UNCD (2016)

Figure 1 shows the export levels of the KSA between 2008 and 2016. In 2008, annual exports started to decrease until 2009, when they started slowly increasing again. In 2010, export growth accelerated until the end of Q1 2012, when exports broadly plateaued. By the end of Q2 2014, exports declined rapidly until the beginning of 2016, when a moderate recovery began.

\subsection{Overview of the KSA's Gross Domestic Product (GDP)}

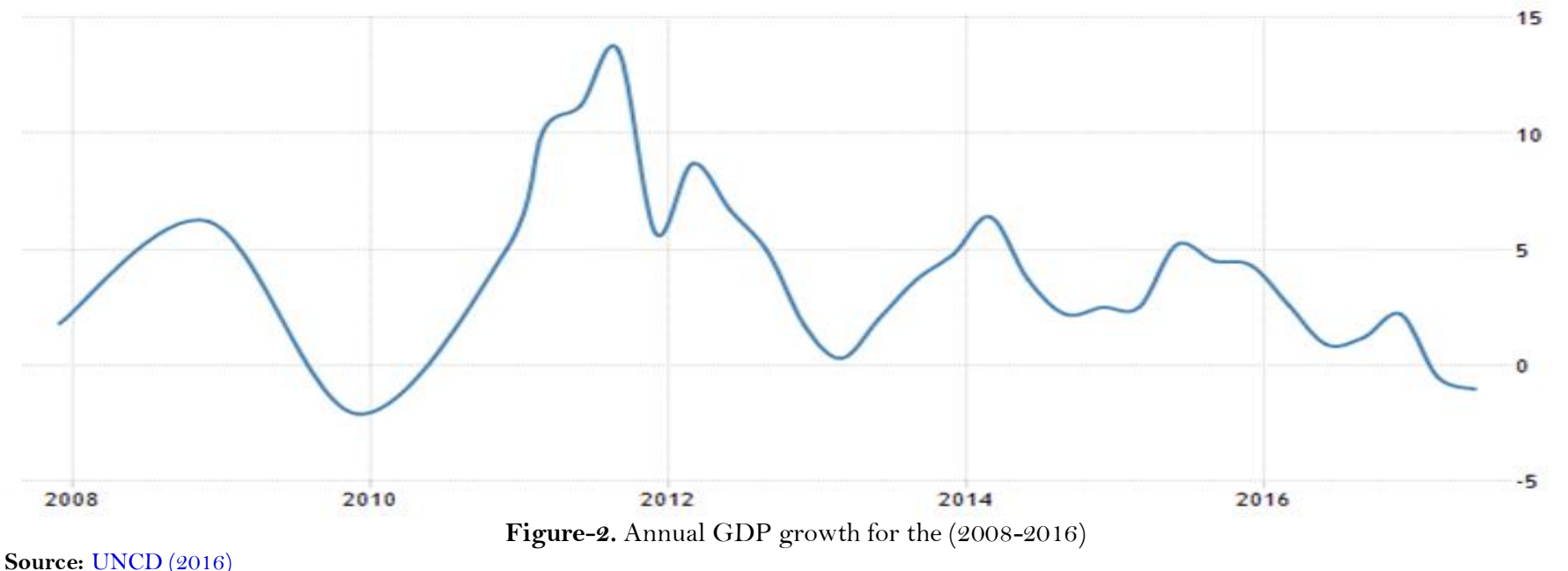

Figure 2 shows how the KSA's GDP growth has experienced a downward trend since 2010, with there being some fluctuations between 2102 and 2016. This is essentially due to two factors: a sharp fall in the price of oil and fluctuations in oil exports. This reflects the narrow dependence of the KSA's economy on oil production and the absence of a diversified economy. 
Annual data for the exchange rate, gross domestic product, and exports were collected from the World Bank's database for the 1980-2016 period.

\section{Literature Review}

This study was conducted with the main objective of investigating the relationship between exports and economic growth in KSA. More specifically, it aims to:

- determine the long-term relationship between exports and economic growth in the KSA;

- examine the short-term relationship between exports and economic growth in the KSA; and

- test the causality patterns between exports and economic growth in the KSA.

The relationship between exports and economic growth in the KSA is still fraught with controversy and divergent views. This research seeks to address this issue by verifying the causal link between these two factors.

Classical economic theory emphasizes the issue of comparative advantage and its relevance as a basis for international trade, such as when one country specializes in the production of certain goods where it has a comparative advantage over other countries.

In addition, classical trade theory emphasizes transportation as a tool to facilitate commodity movements and develop exports among nations. This has led to improved productivity and greater economic gains thanks to economies of scale (Doraisami, 1996; Deme, 2002; Mahadevan, 2009; Ozturk and Acaravci, 2010).

Furthermore, trade exchange contributes to the transfer of knowledge, skills, and the localization of technology, which in turn leads to a) product development and enhanced competitiveness, b) more foreign exchange to purchase imports and buy equipment for local production. It should be noted that these benefits cannot be achieved without an economic and political environment that supports economic growth that balances exports and imports with high productivity and advanced competitiveness in the global market.

A study by Mehrara and Firouzjaee (2011) suggests that export growth will boost GDP through the improvement of human capital, workforce skills, and technology. According to this study, estimating the export demand equations helps in obtaining the relative price and income elasticity, which has important implications for export-led growth policies. Therefore, the greater the income elasticity of the export demand, the more that exports will generate growth (Bahmani-Oskoee et al., 1991). This will also increase the price elasticity and make exports more competitive in the international market (Kumar and Pacheco, 2012).

Furthermore, Khan et al. (2012) examine the long-run correlation among the economic growth, exports, and imports of Pakistan using time series data for the 1972-2009 period. They apply the Engle and Granger (1987) causality test and co-integration via a VECM method in their study. The results show the existence of a long-term correlation between exports, imports, and economic growth in Pakistan.

In conclusion, most previous studies apply co-integration and Granger causality methods in order to examine the influence of exports on economic growth in developed and developing countries. Only a few studies have used alternative models such as the Toda-Yamamoto Granger, ARDL, and Sims causality approaches. All empirical studies use a unit root test to find the stationarity of the time series data in level and first difference. In addition, the augmented Dickey-Fuller test is another well-known approached applied in past studies.

This research will help identify factors that influence economic growth, namely the effect of export growth. As a consequence, this study may aid the KSA's government by shedding some light on the effect of export growth changes in the KSA. The result of this study will establish whether changes in exports have significant consequences for the economic growth of the country. This will contribute to the body of knowledge and help policy formulation. In addition, the study will show the relationship between exports and economic growth.

Ultimately, we will be able to estimate whether export growth is appropriate for boosting the economic growth of a developed or developing country. The research will also act as a reference and guideline for future research.

This study is concerned with the relationship between exports and economic growth, so 37 years of economic data for the 1980-2016 period was studied. It aims to establish whether exports have an effect on economic growth or whether economic growth drives export growth.

\section{Experimental Study}

In completing this study, samples were used based on 37 years of annual data. Data were collected for exports and expressed as a measure of export growth, while economic growth was measured by the gross domestic product (GDP) per capita. All variables are expressed in terms of USD (US dollars). This data were obtained from World Bank and IMF sources.

The methods applied to analyze the datawere a unit root test, Johansen co-integration, and the Granger causality test. Johansen co-integration was used to discover the relationship between exports and economic growth over the long term, while the Granger causality test was used to observe the causality relationship between exports and economic growth. First, however, the unit root test was applied to determine the stationarity of the series at level and first difference by using the augmented Dickey-Fuller test (ADF).

Finally, the EVIEWS econometric software was used to analyze all data and interpret the findings. The collected raw data had to be transformed into information that could help answer the research question and identify the relationship between exports and economic growth.

\subsection{Statistical Method of Analysis}

Many economic variables are non-stationary, so a unit root test, namely the augmented Dickey-Fuller test, was used to analyze the data and ensure stationarity. Following this, the Johansen and Juselius (1988) was used to determine the long-term relationship among the variables. Finally, the famous Granger causality test was applied to examine the causality relationship between exports and economic growth, specifically to identify whether exports affect economic growth or if economic growth drives the demand for more exports in the economy.

This study employed empirical analysis to examine the effects of exports on economic growth. Annual data for the 1980-2016 period were used for all variables in the KSA. The estimating equation for this study was: 
$\mathrm{GDP}_{\mathrm{t}}=\beta_{0}+\beta_{1} \mathrm{EXP}_{\mathrm{t}}+\varepsilon_{\mathrm{t}}$

Where $\mathrm{GDP}_{\mathrm{t}}$ is the gross domestic product for period $t$, and $\mathrm{EXP}_{\mathrm{t}}$ is the total exports for period $t$. In order to avoid autocorrelation, the equation must use the $\log$ for all variables. This was so the percentage of change for independent variables could be seen when the independent variables changed by around $1 \%$. In addition, $\varepsilon_{t}$ is the error term.

$$
\operatorname{lnGDP}{ }_{t}=\beta_{0}+\beta_{1} \operatorname{lnEXP}_{\mathrm{t}}+\varepsilon_{\mathrm{t}}
$$

\subsubsection{Unit Root Test}

In econometrics, many variables are non-stationary, so to ensure that the data were stationary, a unit root test was performed before the co-integration test. This test was also applied to avoid any spurious regression. For this study, the augmented Dickey-Fuller (ADF) test was used. Both tests were used to check the robustness of the results. The ADF test was based on the following regression model, which comprises running a regression of the first in the series against the series lagged once, the sum of lagged difference term, a constant, and a time trend.

$$
\Delta \mathrm{Y}=\beta_{1}+\beta_{2} t+\delta Y_{t-1}+\alpha \sum_{i=1}^{p} \Delta Y_{t-1}+U_{t} \quad(1)
$$

Where, $y_{t}=\left\{E C_{t}, G D P_{t}\right\}, \Delta$ is the differencing operator, $\mathrm{t}$ is the time trend, $\mathrm{P}$ is the number of lagged terms, and $u_{t}$ is the error term as white noise. $\left\{\beta_{1}, \beta_{2}, \delta, \alpha_{1} \ldots, \alpha_{p}\right\}$ is the set of parameters to be estimated. The hypotheses for the ADF unit root test were:

$$
\begin{aligned}
& H_{0}: \delta=0 \text { (unit root/ non stationary) } \\
& H_{1}: \delta \neq 0 \text { (no unit root/ stationary) }
\end{aligned}
$$

The unit hypothesis of the ADF can be rejected if it is found to be negative and significantly different from zero. On the other hand, if we fail to reject $H_{0}$, the variable is non-stationary and also has a unit root in the variable.

\subsubsection{Co-integration Test}

A co-integration test was used in this study to examine the long-term relationship between the variables. Consider the following levels of VAR, with $X_{t}$ defined as the log of exports.

$$
\mathrm{X}_{t}=c+\sum_{j=1}^{p} \Gamma_{j} \Delta X_{t-j}+\varepsilon_{j}
$$

If the variables in $X_{t}$ are I (1), the VAR in Equation (4) is non-stationary. If no co-integration exists, statistical inference is not possible with the usual tests. Given this condition, the difference of the series should be determined, and a first difference VAR of the form should be estimated.

$$
\Delta \mathrm{X}_{t}=c+\sum_{j=1}^{p} \Gamma_{j} \Delta X_{t-j}+\varepsilon_{j}
$$

Integration vectors give rise to the stationary variables. If this is the case, the VAR in Eq. (5) can be written as:

In Eq. (6), $\Pi$ is a rank $r$ matrix that can be divided into

$$
\mathrm{X}_{t}=c+\sum_{j=1}^{p} \Gamma_{j} \Delta X_{t-j}+\prod X_{t-1}+\varepsilon_{t}
$$

$$
\prod=\alpha \beta^{\prime}
$$

Where $\alpha$ is a $3 \times r$ loading matrix and $\beta$ is a $3 \times \mathrm{r}$ matrix of co-integrating vectors, with $r$ being the number of co-integration vectors. Following the Johansen procedure (Ighodaro, 2010) the number of co-integration vectors was tested by using the co-integrated VAR shown in Eq. (6).

\subsubsection{Granger Causality Test}

The Granger causality test was employed to examine the causal relationship between the two variables. If the $p$ values of the variable $Y$ significantly contribute to forecasting the value of another variable $X$, then $Y$ has a Granger causal relationship with $X$ and vice versa. The test was based on the equation below.

$$
\begin{aligned}
& Y_{t}=\gamma_{0}+\sum_{z=1}^{p} \gamma_{z} Y_{t-z}+\sum_{i=1}^{q} \lambda_{i} X_{t-1}+\mu_{t} \\
& X_{t}=\varphi_{0}+\sum_{z=1}^{p} \delta_{z} X_{t-z}+\sum_{i=1}^{q} \Psi_{i} Y_{t-1}+\varepsilon_{t}
\end{aligned}
$$

Where $Y_{\mathrm{t}}$ and $X_{\mathrm{t}}$ are the tested variables, $\mu_{\mathrm{t}}$ and $\varepsilon_{\mathrm{t}}$ are the error terms, and t representsthe time period, and $\mathrm{z}$ and

\begin{tabular}{|c|c|c|c|c|}
\hline & \multicolumn{2}{|l|}{ Intercept } & \multicolumn{2}{|c|}{ Intercept + Trend } \\
\hline & Level & First Difference & Level & First Difference \\
\hline Export & $\begin{array}{l}-1.947212 \\
(0.3079)\end{array}$ & $\begin{array}{l}-4.526633 \\
(0.0009)\end{array}$ & $\begin{array}{l}-2.190321 \\
(0.4804)\end{array}$ & $\begin{array}{l}-4.460786 \\
(0.0058)\end{array}$ \\
\hline Gross Domestic Product (GDP) & $\begin{array}{l}0.521838 \\
(0.9852)\end{array}$ & $\begin{array}{l}-4.050588 \\
(0.0034)\end{array}$ & $\begin{array}{l}-4.441637 \\
(0.0061)\end{array}$ & $\begin{array}{l}-4.441637 \\
(0.0061)\end{array}$ \\
\hline
\end{tabular}
$\underline{\mathrm{i}}$ are the number of lags. The null hypothesis is that $\lambda_{i}={ }_{i}=0$ for all $i$, while the alternative hypothesis is that $\lambda_{i} \neq$ $\mathrm{O}$ and $\mathrm{i}_{\mathrm{i}} \neq \mathrm{O}$ for at the least some $i$. If the is significant, but $i$ s not significant, then $X$ is Granger causal to $Y$. If both coefficients are significant, however, the causality runs both ways.

\section{Results}

\subsection{Unit Root Test Results}

In order to examine the stationary properties of the export and GDP variables, the augmented Dickey-Fuller test produced the results shown in Table 4.1. These results are separated into the level and first difference under constant and constant with trend.

Table-4. Unit root test results

For the export variable, the results revealed that under the intercept, it is non-stationary at level and stationary at the first difference. For level, the probability is 0.6256 and the t-Statistic is -1.2788 , which is not significant. Meanwhile, for the first difference, the probability is 0.0010 and the t-Statistic is -4.6372 , which is a 
significance level of $1 \%$. Under the intercept and trend, it is also clear that level is not significant with a probability of 0.9688 and a t-Statistic of -0.6347 . Meanwhile, exports at the first difference is stationary with a significance level of $10 \%(\mathrm{P}$-value $=0.0804$, t-Statistic $=-3.3510)$.

As for the GDP variable, this is also non-stationary at level with a probability of 0.7600 and a t-Statistic of 0.9416. In contrast, for the first difference under intercept, it is stationary at a significance level of $1 \%$ with a probability of 0.0024 and a t-Statistic of -4.2784 . Under the intercept and trend, meanwhile, the results show it is nonstationary at level with a probability of 0.9093 and a t-Statistic of -1.1134 . At the first difference it is stationary, however, with a probability of 0.0110 and a t-Statistic of -4.2826, showing a significance level of $5 \%$.

\subsection{Co-integration Test Results}

The main focus of this study was to assess how exports and GDP relate to each other in the long term, if such a relationship exists. The unit root test revealed that both variables are non-stationary at level under intercept and intercept with trend, as well as that both are stationary at first difference under both intercept and intercept with trend. Therefore, in order to identify the relationship between exports and GDP, a co-integration test was performed.

Table-4.1.Results of the co-integration test

\begin{tabular}{l|l|l|l|l}
\hline Rank & Max-Eigen Statistic & Critical Value (Eigen) at 5\% & Trace Statistic & Critical Value (Trace) at 5\% \\
\hline $\mathrm{r}=0$ & 14.90479 & 14.26460 & 18.06819 & 15.49471 \\
\hline $\mathrm{r} \leq 1$ & 3.163398 & 3.841466 & 3.163398 & 3.841466 \\
\hline Note: ***, ** and * donate significance at the $1 \%, 5 \%$ and $10 \%$ level, respectively.
\end{tabular}

The results of the co-integration test are given in Table 4.2. These show that both the Maximum Eigen Statistic and the Trace Statistic are present in the KSA's economy at the $5 \%$ level for both two variables. This means that a long-term equilibrium relationship does exist between exports and GDP.

For the null hypothesis, the Trace Statistic is 60.5226, which is higher than the Critical Value (Trace) of 15.4947 at a significance level of $5 \%$. This clarifies that this equation has a long-term relationship between variables at a significance level of $5 \%$. On the other hand, for the Trace Statistic based on rank $\mathrm{r} \leq 1$, the values are lower than the Critical Value (Trace), which exceeds the significance level. At rank $r \leq 1$, the Trace Statistic value is 3.4310 , which is lower than the Critical Value (Trace) of 3.8415 at a significance level of $5 \%$.

However, for the Max-Eigen Statistic, the value at rank $r=0$ is 57.0916, which is higher than the Critical Value (Eigen) of 14.2646, showing a long-term relationship between variables at a $5 \%$ significance level. In addition, at rank $r \leq 1$, the values are lower than the Critical Value (Eigen), so much like for the Trace Statistic, this has also exceeded the significance level. At rank $r \leq 1$, the Max-Eigen statistic value is 3.4310, which is lower than the Critical Value (Eigen) of 3.8415 at a significance level of $5 \%$.

\subsection{Pairwise Granger Causality Test Results}

Since the co-integration test cannot be used to determine the direction of any relationship between the variables, a pairwise Granger causality test was applied to determine whether the paired time series data has a correlation or not (i.e., whether there is a causal relationship between two variables). The correlation for the Granger causality test was applied for all variables. When the F-statistic is lower than the F-critical, it means that there is no Granger causality among the variables. The time series data were checked before running the causality test by applying the unit root and co-integration tests.

Table-4.2. Results of the pairwise Granger causality test

\begin{tabular}{l|l|l|l}
\hline Null Hypothesis & Obs. & F-Statistic & Prob. \\
\hline Export does not Granger cause GDP & 36 & 0.09843 & 0.7557 \\
GDP does not Granger cause export & & 0.01713 & 0.8967 \\
\hline \multicolumn{2}{|l|}{ Note: ***, ** and * denote statistical significance at the 1\%, 5\% and 10\% level, respectively }
\end{tabular}

The Granger causality test results are shown in Table 4.2, representing the pairwise Granger causality among export and GDP.

For the relationship between export and GDP, the results show that the export does not Granger cause GDP, because the significance level is exceeded $(\mathrm{P}$-value $=0.6630, \mathrm{~F}$ - Statistic $=0.1944)$. In contrast, the results also show that GDP does Granger cause export at a significance level of $5 \%(\mathrm{P}$-value $=0.0185$, F-Statistic $=6.3116)$.

In summary, for the correlation between exports and real GDP, exports do not Granger cause GDP but GDP does Granger cause exports.

\section{Conclusion and Remarks}

Table-5. Results of the hypothesis testing

\begin{tabular}{l|l|l}
\hline Hypothesis & Statement of hypothesis & Results \\
\hline H1 & Exports influence GDP & Rejected \\
\hline H2 & GDP influences exports & Accepted \\
\hline Source: Eviews 9 &
\end{tabular}

In conclusion, the hypotheses were accepted or rejected as described in Table 5. The results revealed that GDP significantly influenced exports, so hypothesis $\mathrm{H} 2$ is accepted. However, exports do not have a significant effect on GDP, so hypothesis $\mathrm{H} 1$ is rejected.

In terms of recommendations, the KSA's government should protect domestic markets in order to enhance its aim of building a comparative advantage and economies of scale. However, the government must also formulate 
economic policies that direct more national resources to opening their market in order to learn about new technologies from developed countries and improve productivity. In order to incorporate these superior technologies, the KSA's government should encourage local investors to improve and facilitate the transfer of knowledge from their foreign counterparts.

\section{References}

Bahmani-Oskoee, M., H. Mohtadi and G. Shabsigh, 1991. Exports, growth and causality in LDCs: A re-examination. Journal of Development Economics, 36(2): 405-415. View at Google Scholar | View at Publisher

Deme, M., 2002. An examination of the trade-led growth hypothesis in Nigeria: A co-integration, causality, and impulse response analysis. Journal of Developing Areas, 36(1): 1-15. View at Google Scholar

Doraisami, A., 1996. Export growth and economic growth: A re-examination of some time-series evidence of the Malaysian experience. Journal of Developing Areas, 30(2): 223-230. View at Google Scholar

Engle, R. and C. Granger, 1987. Co-integration and error correction representation, estimation and testing. Econometrica, 55(2): $251-276$. View at Google Scholar | View at Publisher

Ighodaro, C., 2010. Co-integration and causality relationship between energy consumption and economic growth: Further empirical evidence for Nigeria. Journal of Business Economics and Management, 11(1): 97-111. View at Google Scholar $\mid$ View at Publisher

Johansen, S. and K. Juselius, 1988. Hypothesis testing for cointegration vectors with an application to the demand for money in Denmark and Finland. Preprint University of Copenhagen.

Khan, D., U.M. Azra, N. Zaman, E. Ahmad and Y. Shoukat, 2012. Export, imports, and economic growth nexus: Time series evidence from Pakistan. World Applied Sciences Journal, 18(14): 538-542. View at Google Scholar

Kumar, S. and G. Pacheco, 2012. What determines the long run growth rate in Kenya. Journal of Policy Modeling, 34(5): 705-718. View at Google Scholar | View at Publisher

MacKinnon, J., A. Haug and L. Michelis, 1999. Numerical distribution functions of likelihood ratio tests for cointegration. Journal of Applied Econometrics, 14(5): 563-577. View at Google Scholar | View at Publisher

MacKinnon, J.G., 1996. Numerical distribution functions for unit root and cointegration tests. Journal of Applied Econometrics, $11(6)$ : 60 1618. View at Google Scholar | View at Publisher

Mahadevan, R., 2009. The sustainability of export-led growth: The Singaporean experience. Journal of Developing Areas, 43(1): $233-247$. View at Google Scholar | View at Publisher

Mehrara, M. and B.A. Firouzjaee, 2011. Granger causality relationship between export growth and GDP growth in developing countries: Panel cointegration approach. International Journal of Humanities and Social Science, 1(16): 223-231. View at Google Scholar

Ozturk, I. and A. Acaravci, 2010. Testing the export-led growth hypothesis: Empirical evidence from Turkey. Journal of Developing Areas, 44(1): 245-254. View at Google Scholar | View at Publisher

UN Cometrade Database, 2016. UN trade statistics. Retrieved from https://comtrade.un.org/.

\section{Appendices}

\section{Appendix A: Unit Root Test}

Null Hypothesis: LEX has a unit root

Exogenous: Constant

Lag Length: O (Automatic - based on SIC, maxlag=9)

\begin{tabular}{l|l|l|l|l}
\hline & & & t-Statistic & Prob.* $^{*}$ \\
\hline Augmented Dickey-Fuller test statistic & -1.947212 & 0.3079 \\
\hline Test critical values: & $1 \%$ level & -3.626784 & \\
\hline & $5 \%$ level & & -2.945842 & \\
\hline & $10 \%$ level & -2.611531 & \\
\hline
\end{tabular}

*MacKinnon (1996) one-sided p-values.

Null Hypothesis: D(LEX) has a unit root

Exogenous: Constant

Lag Length: O (Automatic - based on SIC, maxlag=9)

\begin{tabular}{l|l|l|l|l}
\hline & & t-Statistic & Prob.* $^{*}$ \\
\hline Augmented Dickey-Fuller test statistic & -4.526633 & 0.0009 \\
\hline Test critical values: & $1 \%$ level & -3.632900 & \\
\hline & $5 \%$ level & -2.948404 & \\
\hline & $10 \%$ level & -2.612874 & \\
\hline
\end{tabular}

*MacKinnon (1996) one-sided p-values.

Null Hypothesis: LY has a unit root

Exogenous: Constant

Lag Length: O (Automatic - based on SIC, maxlag=9)

\begin{tabular}{l|l|l|l|l}
\hline & & & t-Statistic & Prob.* $^{*}$ \\
\hline Augmented Dickey-Fuller test statistic & 0.521838 & 0.9852 \\
\hline Test critical values: & $1 \%$ level & & -3.626784 & \\
\hline & $5 \%$ level & & -2.945842 & \\
\hline & $10 \%$ level & & -2.611531 & \\
\hline
\end{tabular}

*MacKinnon (1996) one-sided p-values.

Null Hypothesis: D(LY) has a unit root

Exogenous: Constant

Lag Length: O (Automatic - based on SIC, maxlag=9)

\begin{tabular}{l|l|l|l|l}
\hline & & & \\
\hline & & t-Statistic & Prob. $^{*}$ \\
\hline Augmented Dickey-Fuller test statistic & -4.050588 & 0.0034 \\
\hline Test critical values: & $1 \%$ level & -3.632900 & \\
\hline & $5 \%$ level & & -2.948404 & \\
\hline & $10 \%$ level & -2.612874 & \\
\hline
\end{tabular}

*MacKinnon (1996) one-sided p-values. 


\section{Appendix B: Johansen Co-Integration Test Results}

Date: 10/08/17 Time: 12:47

Sample (adjusted): 19892016

Included observations: 28 after adjustments

Trend assumption: Linear deterministic trend

Series: DLEX DLY

Lags interval (in first differences): 1 to 7

Unrestricted Cointegration Rank Test (Trace)

\begin{tabular}{|c|c|c|c|c|}
\hline Hypothesized & & Trace & 0.05 & \\
\hline No. of CE(s) & Eigenvalue & Statistic & Critical Value & Prob.** \\
\hline None $*$ & 0.412756 & 18.06819 & 15.49471 & 0.0200 \\
\hline At most 1 & 0.106830 & 3.163398 & 3.841466 & 0.0753 \\
\hline \multicolumn{5}{|c|}{$\begin{array}{l}\text { Trace test indicates } 1 \text { cointegratingegn }(\mathrm{s}) \text { at the } 0.05 \text { level } \\
\text { * denotes rejection of the hypothesis at the } 0.05 \text { level } \\
\text { **MacKinnon } \text { et al. (1999) p-values }\end{array}$} \\
\hline \multicolumn{5}{|c|}{ Unrestricted Cointegration Rank Test (Maximum Eigenvalue) } \\
\hline Hypothesized & & Max-Eigen & 0.05 & \\
\hline No. of CE(s) & Eigenvalue & Statistic & Critical Value & Prob.** \\
\hline None $*$ & 0.412756 & 14.90479 & 14.26460 & 0.0396 \\
\hline At most 1 & 0.106830 & 3.163398 & 3.841466 & 0.0753 \\
\hline
\end{tabular}

Max-eigenvalue test indicates 1 cointegratingeqn(s) at the 0.05 level

* denotes rejection of the hypothesis at the 0.05 level

***MacKinnon et al. (1999) p-values

Unrestricted Cointegrating Coefficients (normalized by $b^{\prime *} \mathrm{~S}_{1} 1^{*} \mathrm{~b}=\mathrm{I}$ ):

\begin{tabular}{l|l|l|l|l}
\hline DLEX & DLY & & & \\
\hline-15.14379 & 0.170214 & & & \\
\hline 15.92390 & -8.804196 & & & \\
\hline \multicolumn{5}{l}{} \\
\hline Unrestricted Adjustment Coefficients (alpha): & & \\
\hline D(DLEX) & -0.028861 & -0.020891 & & \\
\hline D(DLY) & -0.046087 & -0.010213 & & \\
\hline
\end{tabular}

1 Cointegrating Equation(s): $\quad$ Log likelihood $\quad 89.00399$

Normalized cointegrating coefficients (standard error in parentheses)

\begin{tabular}{l|l|l|l|l}
\hline DLEX & DLY & & & \\
\hline 1.000000 & -0.011240 & & & \\
\hline & $(0.13515)$ & & & \\
\hline
\end{tabular}

Adjustment coefficients (standard error in parentheses)

\begin{tabular}{l|l|l|l|l}
\hline $\mathrm{D}(\mathrm{DLEX})$ & 0.437072 & & & \\
\hline & $(0.31738)$ & & & \\
\hline $\mathrm{D}(\mathrm{DLY})$ & 0.697930 & & & \\
\hline & $(0.27643)$ & & & \\
\hline
\end{tabular}

\section{Appendix C: Granger Causality Test Results}

Pairwise Granger Causality Tests

Date: 10/08/17 Time: 12:45

Sample: 19802016

\begin{tabular}{l|l|l|l} 
Lags: 1 & \multicolumn{1}{l}{} \\
\hline Null Hypothesis: & Obs & F-Statistic & Prob. \\
\hline LY does not Granger Cause LEX & 36 & 0.09843 & 0.7557 \\
\hline LEX does not Granger Cause LY & & 0.01713 & 0.8967 \\
\hline
\end{tabular}

